\title{
School closures in Chile: Access to quality alternatives in a school choice system
}

\author{
Cierre de escuelas en Chile: Acceso a alternativas de calidad \\ en un sistema de elección escolar
}

\author{
GREGORY ElACQUA* \\ Matías MARTÍNEZ* \\ Humberto SANTOS* \\ DANIELA URBINA*
}

\begin{abstract}
In this paper, we analyze the schooling alternatives of families that could face school closure. This article identifies, characterizes, and georeferences the institutions classified as low-performing by the SEP Law along with their closest alternatives. The findings indicate that a significant number of families do not have any quality alternatives nearby, particularly families in rural areas and/ or in schools with a high percentage of low SES students. Additionally, when admissions barriers and family preferences are incorporated in the analysis, school alternatives are considerably reduced. Alternatives are further reduced when using a more stringent definition of school quality.
\end{abstract}

Key words: Accountability, School choice, Education policy, School closure.

JEL Classification: $I 24, I 28$.

\section{Resumen}

Para analizar las opciones que tendrían las familias frente al cierre de su escuela este artículo identifica, caracteriza y georreferencia a los establecimientos clasificados como de bajo desempeño por la Ley SEP y a sus alternativas cercanas. Los resultados indican que un porcentaje importante de las familias no tiene alternativas de calidad, principalmente aquellas que viven en sectores rurales y/o que pertenecen a escuelas vulnerables. Adicionalmente, al incorporar las barreras de entrada de las escuelas y las preferencias de las familias, dichas opciones se reducen considerablemente, al igual que al utilizar una definición más exigente de calidad.

Palabras clave: Accountability, Elección escolar, Política educativa, Cierre de escuelas.

Clasificación JEL: I24, I28.

* Instituto de Políticas Públicas, Facultad de Economía y Empresa, Universidad Diego Portales. 


\section{INTRODUCTION}

The current focus on accountability in Latin American education developed in response to frustration with the low performance on international tests compared to other more developed nations and the widening socioeconomic and racial test score gaps. Scholars have argued that low performance and inequities could be explained by the lack of performance incentives in schooling in the region (e.g. Hanushek and Woessmann, 2012).

Governments around the globe have instituted two different accountability mechanisms to improve the quality and equity of schooling systems. The first mechanism is advocated by economists such as Milton Friedman (e.g. Friedman, 1962), and other social scientists, such as John Chubb and Terry Moe (e.g. Chubb and Moe, 1990), who have argued that the problems of low performance result from the lack of competition between schools and the lack of opportunities for low-income children to abandon their low-performing neighborhood public schools. They advocate for more competition in the schooling system through the provision of educational vouchers that would enable families to freely choose schools for their children. State-driven accountability is an alternative mechanism that aims to improve school quality and close the test score gaps. State accountability systems reward and punish schools by allocating funding according to whether the school meets certain performance criteria. Proponents have emphasized the importance of setting standards, aligning the curriculum with those standards, developing assessments, holding schools accountable for their outcomes, and applying sanctions to low-performing schools (Brady, 2003; Spreng, 2005; Figlio and Getzler, 2002).

Although school choice and state accountability are two of the most hotly debated education reform topics, relatively little is known about their benefits and risks. The evidence is limited because few schooling systems have implemented school choice and state accountability plans. Researchers can gain insight into this debate by examining education systems where school choice and state accountability coexist. Chile has recently incorporated accountability into its long-established universal system of school choice that finance public and private schooling options.

In 2008, the Chilean legislature enacted the Adjusted Voucher Law (Ley de Subvención Preferencial or SEP). The SEP Law recognizes that it is more costly to educate poor students by introducing an extra per-pupil subsidy (50 percent over the base voucher) for students classified as low socioeconomic status by the Ministry of Education and for schools with a high concentration of disadvantaged students. The additional per-student voucher is tied to an increased role of the Ministry of Education in monitoring and classifying schools based on student performance and holding them accountable for their outcomes (Elacqua and Santos, in press). The SEP Law also forbids participating schools from using parental interviews and admissions tests to select and expel students. In addition, participating schools cannot charge co-payments to students classified as disadvantaged.

The SEP Law classifies schools into one of three categories: "Autonomous", "Emerging" or "In Recovery". The categories are based on a school's adjusted national test scores (SIMCE) over time and on other indicators, such as retention rates, school integration, and teacher evaluations. The classification affects 
the degree of autonomy schools have in spending additional resources. In cases where schools present systematically high educational results (last three years), they are classified as "Autonomous" and have flexibility in the way they choose to spend the additional SEP resources. In cases where schools meet minimum standards, but do not reach high standards, they are classified as "Emerging" and they are required to present a plan to the Ministry of Education on how they plan to use the additional resources. Finally, schools with persistent low results are classified as "In Recovery" and the Ministry of Education develops an improvement plan with the school, restricting autonomy on the allocation of SEP resources. If the school does not fulfill its learning goals over the following four years, it loses the official license to operate and receive public resources, which in practice implies its closure. ${ }^{1}$ The Education Quality Assurance Law (Ley de Aseguramiento de la Calidad de la Educación), which was enacted in 2011 includes similar measures that can lead to the Ministry's intervention or closure of subsidized schools, whether they are administered by a municipality or a private school owner. ${ }^{2}$

The closure of low-performing schools has emerged as a policy response in some countries due to the lack of evidence on the effectiveness of a range of interventions ${ }^{3}$ intended to improve the performance of these schools (Smarick, 2010). Advocates of school closure maintain that after years of investment in interventions aimed to improve low achieving schools performance, the results are fairly dismal. Proponents argue that closure is the most effective measure for schools that are chronically under-performing and that simply cannot be fixed (e.g. Brady, 2003). This assertion rests on the assumption that students enrolled in failing schools could be transferred to higher-performing schools. Advocates also maintain that the threat of closure creates an incentive for other low-performing schools to improve (e.g. Smarick, 2010).

However, as the push for school closure has intensified, a series of critiques have identified the costs of this measure. Perhaps the most persistent criticism is that closure increases the risk of exacerbating inequities. Most empirical studies in the United States confirm that students enrolled in failing schools often have

1 Strictly speaking, the loss of official recognition implies that the school loses public funding, but could continue to operate as a privately funded school.

2 This Law establishes the Superintendency of Education (Superintendencia de Educación) responsible for supervising school administration, and the Education Quality Agency (Agencia de Calidad de la Educación) responsible for evaluating (classifying) and issuing guidelines on how to improve the quality of all public and private schools.

3 The first level of these interventions does not imply disruptive changes to the schools (Murphy and Meyers, 2007). For example, preparation of improvement plans by the schools themselves, the provision of technical assistance and teacher training. The second group of measures is aimed at changing certain specific aspects of schools; including changing schools' principal and reorganizing the school (Mathis, 2009). If the school does not improve its performance, tougher interventions are applied that aim to produce a radical change in the school. These include the "reconstitution of the school", including removing the director, teachers and administrative staff (The Education Commission of the States, 2002). Another of these interventions is to "take over" the school, either by the State or by a private organization, which also implies a change of teachers, administrative staff and management (The Center for Comprehensive School Reform and Improvement, 2005). 
limited quality options in their neighborhoods and they are often transferred to another low-performing school. For example, according to Dillon's study (2008) in Florida, Texas and California, only a small proportion of students in very specific locations benefited from school closure. This is largely due to the long distances to schooling options and the capacity restrictions of the higherperforming schools (Dillon, 2008). Likewise, Kim and Sunderman (2004) in their study on student transfers in ten states in the United States, find that most students were sent to schools that do not perform significantly better and, in addition, most have high poverty levels. In these cases, changing school produces a negative externality for the student and community (Hanushek et al., 2004).

Opponents of school closure also point out that in countries where this measure has been applied, such as in the United States and England, ${ }^{4}$ it has generated strong resistance from the school community and public opinion (Murphy and Meyers, 2007; Spreng, 2005). This likely explains why other countries have resisted incorporating this measure in their accountability programs.

Although the sanctions of the SEP Law have also generated a public debate on school closure in Chile, relatively little is known about their effectiveness. Specifically, there is no empirical evidence that examines the scenarios faced by parents in chronically low-performing schools. The objective of this research is to analyze the schooling options available for parents with children in failing schools. We accomplish this first by identifying low-performing schools and their closest available higher-performing school options. Next, we incorporate the school choice component of the Chilean system into the analysis by considering barriers to entry for parents in higher performing local schooling options (costs, school mission, selection). This study provides evidence to policymakers in Chile and in other countries to help to anticipate potential problems associated with closing failing schools.

The paper is organized as follows. The methodology and the data are described in the following section. Section 3 discusses the empirical strategy and presents the main findings. Finally, section 4 presents the conclusions and policy implications.

\section{Data And Methodology}

The data for the analyses presented here are drawn from four administrative sources at the Ministry of Education: the SEP school classification school files, the national school GIS data, the school directory files, and the School Quality Assessment System (Sistema de Medición de la Calidad de la Educación-SIMCE). The SEP classification files contain a rank ("Autonomous", "Emerging" or "In Recovery") for every public and private voucher school. We define failing schools in this study as "In Recovery". The school coordinate data include an address and coordinates for 11,648 public and private voucher preschools and primary

4 In the United States the "No Child Left Behind" Law (2001) introduced a series of objectives and sanctions in schools, while in England it was the "Education and Inspection" Law (2006). 
and secondary schools. We used Google Earth Pro to obtain the coordinates of the missing schools using their addresses. The school directory contains a record for every school on the school's ownership type and mission (Catholic, Protestant, for-profit, etc.), subsidies received from the per-pupil voucher and SEP, transfers from the municipalities, and school fees. The SIMCE files include a test score for every public and private school student in grades 4,8 , and 10 in mathematics, language, sciences, history, and geography. This study focuses on primary schools. In addition to information on test scores, the SIMCE files indicate the highest level of education obtained by the student's parents and other demographic information. These four files were linked and exported to the ArcGIS Desktop software to conduct spatial analyses. The final database included 7,997 primary schools.

We conduct four complementary analyses with these data. First, we characterize the "In Recovery" schools based on the socioeconomic level, location and ownership type. Next we simulate the scenario faced by families with children enrolled in "In Recovery" schools in the event that they do not meet the improvement goals set out in the SEP Law and are closed. For this static analysis, we made the following assumptions: i) the low-performing schools do not improve, 5 ii) the alternative schools do not change their admission policies and do not increase their capacity to receive additional students and iii) there is no entry of new high-performing schools. The validity of these assumptions can only be studied a few years after the implementation of the SEP Law. Given these conditions, georeferenced information of the schools was used and the closest higher-performing alternatives for students in "In Recovery" schools were identified. This analysis assumes that prior to closing a low-performing school there must be higher quality nearby alternatives. ${ }^{6}$ This approach assumes that governments must guarantee access to quality education for all students, regardless of their place of residence. While many parents may be willing to travel greater distances or pay a higher price for their children to receive higher quality education (Gallego and Hernando, 2009; Chumacero, Gomez and Paredes, 2011), by changing them to a more distant school they are being forced to take on higher costs (e.g. in transport) that they probably already evaluated when choosing their current school. In addition, there is evidence that indicates that a high percentage of low-SES parents choose schools relatively close to their place of residence; in other words, students who have a higher probability of attending "In Recovery" schools tend to travel shorter distances. For example, Alves et al. (2012) find that $70 \%$ of low SES fourth grade primary students in Greater Santiago (none of the parents completed secondary school), attend schools within a $1 \mathrm{~km}$ radius of their residence. Over half of these students travel 600 meters or less to school (Alves et al., 2012).

5 There is evidence that shows that due to the pressures from the sanctions contained in the accountability systems, low-performing schools change their teaching and management practices, which can lead to better educational outcomes (e.g. Rouse et al., 2007, Allen and Burgess, 2012).

6 A school is considered to be higher quality if it has a higher SEP classification. 
The third analysis incorporates access barriers to higher quality alternatives near the low-performing schools, given that the nature of the Chilean school choice system creates limits to free entry to any school. In particular, there is some evidence that suggests that schools administer interviews and cognitive tests to select students and families. In addition, families discard certain schools prior to applying due to economic considerations or preferences for certain kinds of educational missions (e.g. Evangelical). In terms of the selection practices of schools, prior research suggests that they tend to choose higher ability and higher-SES students in order to increase their educational results and thereby improve their market reputation (Lacireno-Paquet et al., 2002; Lubienski et al., 2009; Contreras, et al., 2010). The mechanisms used by schools to select students vary from country to country ${ }^{7}$ however, the most common are admission tests, monthly fees and interviews with the parents prior to registration. ${ }^{8}$ In terms of family preferences, the research on school choice shows that parents not only value the proximity of schools to their residence and the academic results, but also a school's values and student demographics (Fiske and Ladd, 2000; Schneider et al., 2000; Elacqua et al., 2006). For example in Chile, Elacqua et al. (2006) find that $87 \%$ of parents consider schools in their choice sets with similar student demographics and nearly $70 \%$ only consider schools from the same religious background (Secular, Catholic or Protestant).

Finally, the fourth analysis examines how the number of higher quality school alternatives available to children in low-performing schools is sensitive to the definition of school quality. For instance, when higher quality is defined by higher test scores in each school rather than the higher SEP classification, the number of higher-performing options declines for parents with children enrolled in "In Recovery" schools.

\section{Empirical Strategy and Results}

\subsection{Low-performing schools in Chile: the SEP Law}

Of the 7,997 primary schools in the database, 396 (5\%) were classified as "In Recovery", while 1,214 (15.2\%) were classified as "Autonomous". Among

$7 \quad$ The General Education Law (Ley General de Educación or LGE), enacted in 2009, bans student selection by schools through sixth grade. Nevertheless, according to SIMCE parent questionnaires, $80 \%$ of private voucher schools in Chile continue to apply some form of student selection based on student ability, family socioeconomic level or religion.

8 While this is true, some studies suggest that student distribution in schools depends mainly on parental preferences (i.e. self-selection) more than on selection by schools (e.g. Gallego and Hernando, 2009). This study assumes that barriers to entry are an active restriction for a range of families, whose choice is determined by the set of schools that they in practice consider accessible. These restrictions may be more significant in the case of families from lower socioeconomic levels, which are overrepresented in the "In Recovery" schools. 
the "Emerging" schools, only 1,990 (24.9\%) were classified in this category based on their performance outcomes, while the rest $(4,397)$ were included in this category due to insufficient information to rank them. In terms of total enrollment in each type of school, the data shows that $7.5 \%$ of primary school students attend "In Recovery" schools (139,474 students), while 32.1\% attend "Autonomous" schools $(599,121$ students). The remainder $(60.4 \%)$ attends "Emerging" schools (1,126,905 students).

In terms of geographic distribution, three regions in Northern Chile-Tarapacá, Antofagasta and Atacama- and the Metropolitan Region of Santiago have the highest national percentages of "In Recovery" schools and enrollments. Meanwhile, two regions - Arica and Parinacota, and Magallanes- do not have any schools classified in the low-performing category (see Tables 1 and 2). Furthermore, $92.7 \%$ of "In Recovery" schools and 95.2\% of enrollments are located in urban areas. Most rural schools (95.8\%) are classified as "Emerging" due to their low total enrollment. ${ }^{9}$

TABLE 1

SCHOOLS BY SEP LAW CLASSIFICATION 2009-2010 AND REGION

\begin{tabular}{|c|c|c|c|c|c|c|c|c|}
\hline \multirow{2}{*}{ Region } & \multicolumn{2}{|c|}{ Autonomous } & \multicolumn{2}{|c|}{ Emerging } & \multicolumn{2}{|c|}{ In Recovery } & \multicolumn{2}{|c|}{ Total } \\
\hline & $(\mathrm{N})$ & $(\%)$ & $(\mathrm{N})$ & $(\%)$ & $(\mathrm{N})$ & $(\%)$ & $(\mathrm{N})$ & $(\%)$ \\
\hline Tarapacá & 10 & 8.9 & 82 & 73.2 & 20 & 17.9 & 112 & 100.0 \\
\hline Antofagasta & 11 & 9.2 & 93 & 78.2 & 15 & 12.6 & 119 & 100.0 \\
\hline Atacama & 17 & 17.2 & 72 & 72.7 & 10 & 10.1 & 99 & 100.0 \\
\hline Coquimbo & 67 & 12.6 & 453 & 85.3 & 11 & 2.1 & 531 & 100.0 \\
\hline Valparaíso & 115 & 15.9 & 556 & 77.0 & 51 & 7.1 & 722 & 100.0 \\
\hline O'Higgins & 87 & 18.2 & 368 & 77.0 & 23 & 4.8 & 478 & 100.0 \\
\hline Maule & 112 & 16.8 & 531 & 79.8 & 22 & 3.3 & 665 & 100.0 \\
\hline Biobío & 214 & 18.5 & 903 & 78.0 & 41 & 3.5 & 1,158 & 100.0 \\
\hline Araucanía & 75 & 7.1 & 977 & 92.1 & 9 & 0.8 & 1,061 & 100.0 \\
\hline Los Lagos & 77 & 9.0 & 775 & 90.2 & 7 & 0.8 & 859 & 100.0 \\
\hline Aysén & 9 & 15.8 & 47 & 82.5 & 1 & 1.8 & 57 & 100.0 \\
\hline Magallanes & 11 & 21.2 & 41 & 78.8 & 0 & 0.0 & 52 & 100.0 \\
\hline Metropolitana & 354 & 22.5 & 1,037 & 65.9 & 182 & 11.6 & 1,573 & 100.0 \\
\hline Los Ríos & 46 & 10.4 & 391 & 88.7 & 4 & 0.9 & 441 & 100.0 \\
\hline Arica y Parinacota & 9 & 12.9 & 61 & 87.1 & 0 & 0.0 & 70 & 100.0 \\
\hline Total & 1,214 & 15.2 & 6,387 & 79.9 & 396 & 5.0 & 7,997 & 100.0 \\
\hline
\end{tabular}

Source: Authors' calculations.

$\overline{9}$ See footnote 13 . 
TABLE 2

PRIMARY ENROLLMENT BY SEP LAW CLASSIFICATION 2009-2010 AND REGION

\begin{tabular}{|c|c|c|c|c|c|c|c|c|}
\hline \multirow{2}{*}{ Region } & \multicolumn{2}{|c|}{ Autonomous } & \multicolumn{2}{|c|}{ Emerging } & \multicolumn{2}{|c|}{ In Recovery } & \multicolumn{2}{|c|}{ Total } \\
\hline & $(\mathrm{N})$ & $(\%)$ & $(\mathrm{N})$ & $(\%)$ & $(\mathrm{N})$ & $(\%)$ & $(\mathrm{N})$ & $(\%)$ \\
\hline Tarapacá & 8,645 & 23.2 & 20,886 & 56.2 & 7,656 & 20.6 & 37,187 & 100.0 \\
\hline Antofagasta & 7,920 & 11.5 & 53,269 & 77.6 & 7,490 & 10.9 & 68,679 & 100.0 \\
\hline Atacama & 9,949 & 27.9 & 21,406 & 60.0 & 4,348 & 12.2 & 35,703 & 100.0 \\
\hline Coquimbo & 29,301 & 35.2 & 49,942 & 59.9 & 4,104 & 4.9 & 83,347 & 100.0 \\
\hline Valparaíso & 47,126 & 25.5 & 122,463 & 66.2 & 15,353 & 8.3 & 184,942 & 100.0 \\
\hline O’Higgins & 36,496 & 35.6 & 58,196 & 56.8 & 7,696 & 7.5 & 102,388 & 100.0 \\
\hline Maule & 47,945 & 40.7 & 64,146 & 54.4 & 5,820 & 4.9 & 117,911 & 100.0 \\
\hline Biobío & 101,528 & 43.1 & 121,716 & 51.6 & 12,474 & 5.3 & 235,718 & 100.0 \\
\hline Araucanía & 33,049 & 28.5 & 80,522 & 69.5 & 2,236 & 1.9 & 115,807 & 100.0 \\
\hline Los Lagos & 33,791 & 33.6 & 63,946 & 63.6 & 2,755 & 2.7 & 100,492 & 100.0 \\
\hline Aysén & 4,151 & 33.6 & 7,908 & 64.0 & 305 & 2.5 & 12,364 & 100.0 \\
\hline Magallanes & 5,422 & 31.4 & 11,844 & 68.6 & 0 & 0.0 & 17,266 & 100.0 \\
\hline Metropolitana & 208,190 & 30.5 & 406,969 & 59.5 & 68,306 & 10.0 & 683,465 & 100.0 \\
\hline Los Ríos & 19,829 & 44.4 & 23,907 & 53.5 & 931 & 2.1 & 44,667 & 100.0 \\
\hline Arica y Parinacota & 5,779 & 22.6 & 19,785 & 77.4 & 0 & 0.0 & 25,564 & 100.0 \\
\hline Total & 599,121 & 32.1 & $1,126,905$ & 60.4 & 139,474 & 7.5 & $1,865,500$ & 100.0 \\
\hline
\end{tabular}

Source: Authors' calculations.

Regarding the socioeconomic level of the "In Recovery" schools, there are no low-performing schools in groups D and E (Middle-High and High). ${ }^{10}$ Most "In Recovery" schools (94.2\%) are in groups A and B (Low and Middle-Low) and only a small percentage (5.8\%) are in group C (Middle). This distribution is similar to the percentages of "In Recovery" enrollment in the socioeconomic group categories.

Finally, when classifying schools by owner type, over $75 \%$ of "In Recovery" schools and enrollments is municipal (see Tables 3 and 4). Among the private voucher schools, the largest group is the free secular schools ${ }^{11}(15.4 \%)$, followed by secular schools that charge limited tuition-less than 1 USE- $(8.3 \%){ }^{12}$

10 SIMCE classifies schools into five socioeconomic groups: Low (A), Middle-Low (B), Middle (C), Middle-High (D) and High (E). The variables used for this classification are parents' highest level of education, the monthly income of the household reported by the students' guardians in SIMCE questionnaires, and the School Vulnerability Index (IVESINAE), calculated by JUNAEB, the national school breakfast and lunch program.

11 Religious schools are Catholic, Protestant (Evangelical, Lutheran, Methodist, Pentecostal, Anglican, Presbyterian, Baptist and Episcopalian) or other religions (Greek, Persian, Serbian, Ukrainian and Armenian Orthodox, Church of Jesus Christ of Latter Day Saints (Mormons), Seventh Day Adventists and Jehovah's Witnesses. Secular schools do not ascribe to any particular church or faith.

12 USE (Unidad de Subvención Educacional). USE 2011 = 18,190.928 CLP. (Source: MINEDUC). 


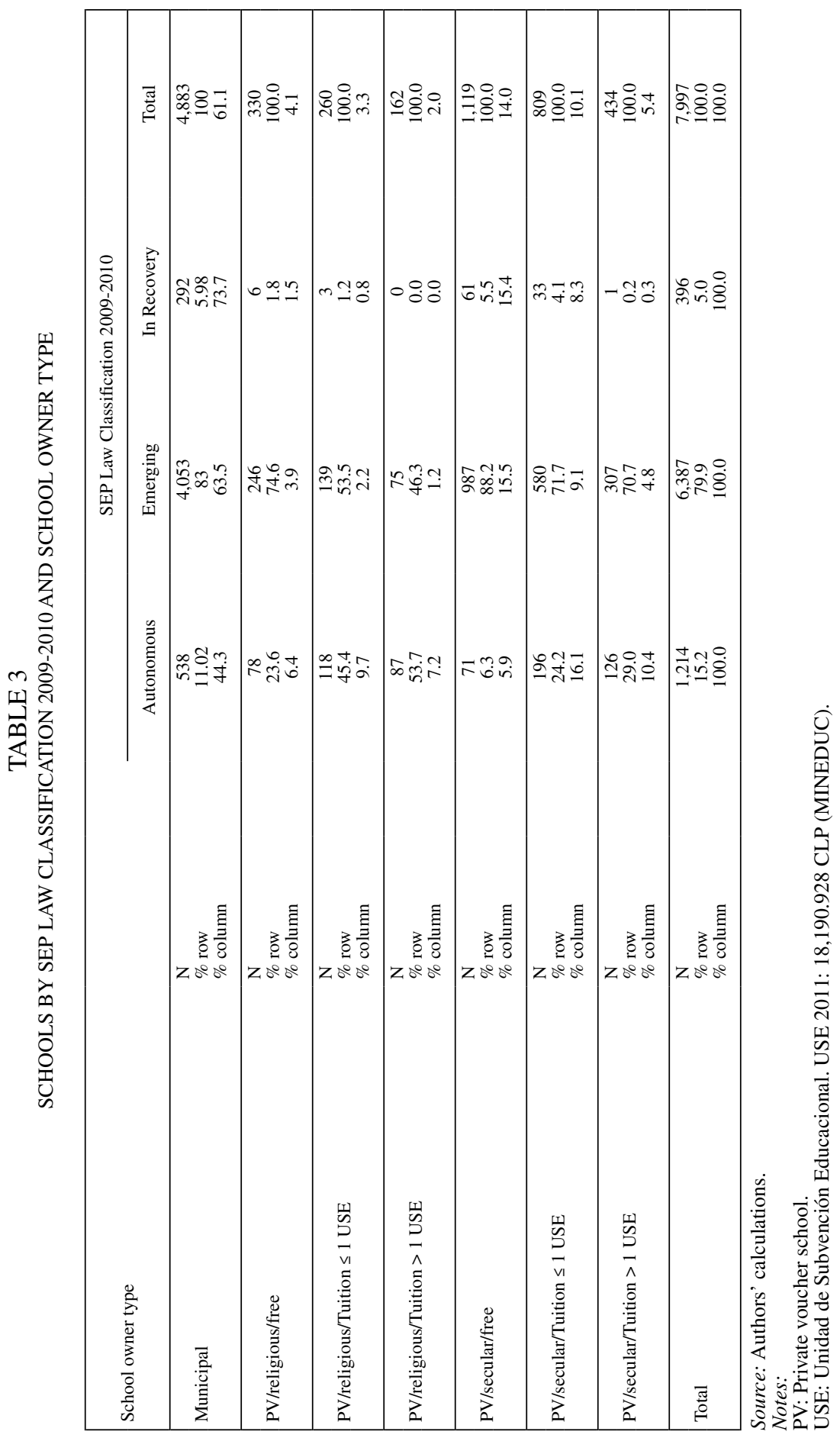




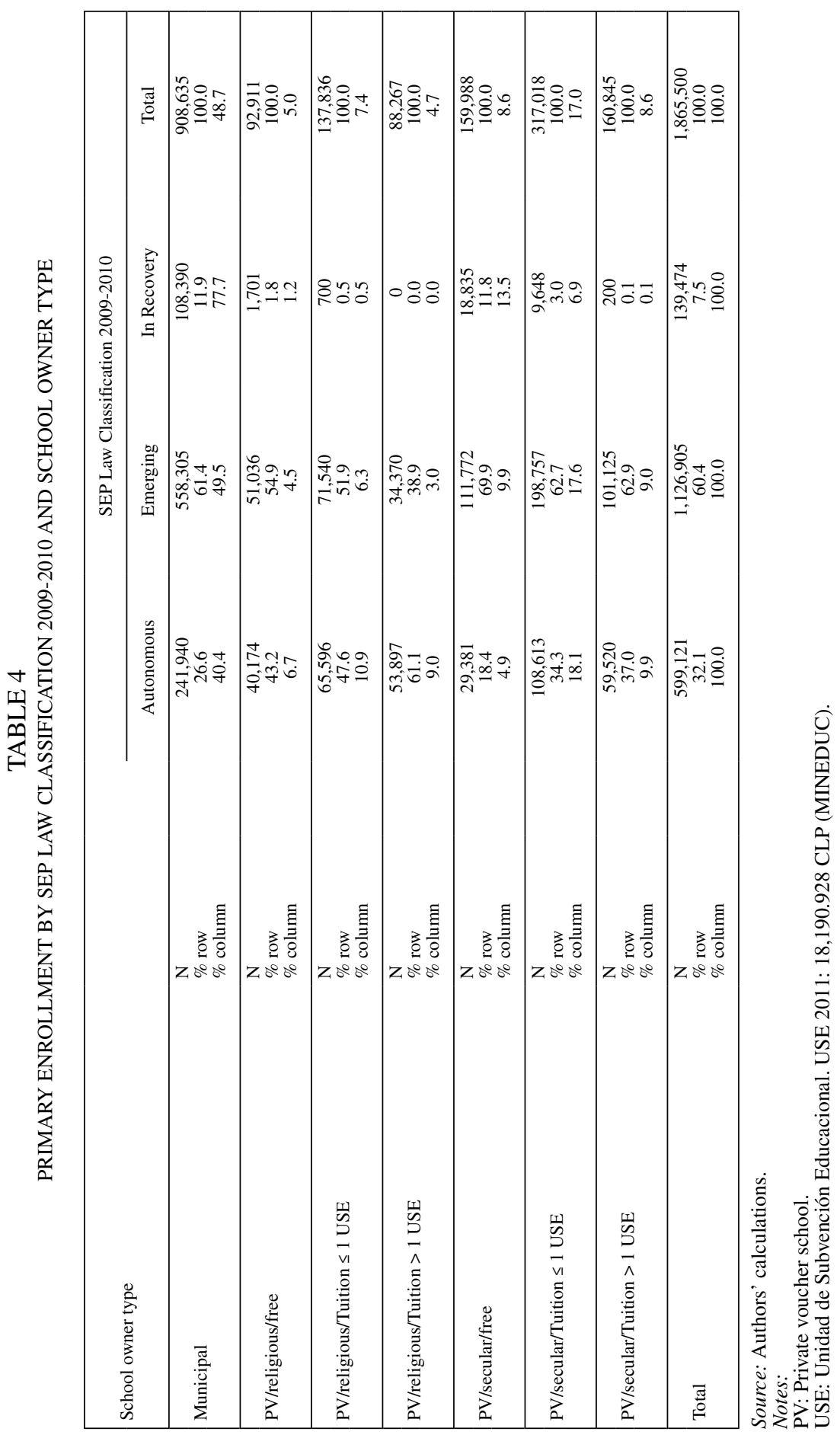




\subsection{Higher quality alternatives}

To geographically locate the schooling alternatives near the "In Recovery" schools, we used an ArcGIS Desktop software analysis tool called buffer, which captures all schools within around the "In Recovery" schools. For the effects of this analysis, "Autonomous" and "Emerging" schools ${ }^{13}$ are considered higherperforming alternatives. We generated a radius of 1, 2, 3 and $5 \mathrm{~km}$ around each of the 396 "In Recovery" schools and the number of higher classified alternatives was calculated for each of them. Tables 5, 6, 7 and 8 present the results of this exercise.

As expected, the number of higher-performing alternatives available increases when using a larger radius around the schools. Another unsurprising result is that a significant proportion of rural schools do not have nearby higher quality alternatives. Even within a $5 \mathrm{~km}$ radius, almost a third (27.6\%) of rural schools do not have higher classified alternatives. On the other hand, most urban schools have a higher-performing alternative within $1 \mathrm{~km}(92.4 \%)$ radius, increasing to nearly $100 \%$ within a $5 \mathrm{~km}$ radius $(99.5 \%)$. The results also show that the number of "Emerging" or "Autonomous" schools increases with the socioeconomic level of the "In Recovery" school. For example, with a $2 \mathrm{~km}$ radius, $100 \%$ of schools in the Middle group have a higher quality alternative. This percentage is $87.7 \%$ for "In Recovery" schools from the Low socioeconomic group.

To complement the above analysis, the distance was calculated between each of the "In Recovery" schools and the nearest higher classified school. Table 9 presents the results of this exercise. Considering all of the "In Recovery" schools, the closest higher classified school is located, on average, $0.84 \mathrm{~km}$ away. However, and consistent with the results presented above, this distance is significantly greater for rural schools $(4.39 \mathrm{~km})$. In the case of urban schools, the closest higher classified school is located, on average, $0.56 \mathrm{~km}$ away. Separating schools by socioeconomic levels reveals that distance to the nearest quality school increases with the socioeconomic level of the "In Recovery" schools. While parents with children enrolled in "In Recovery" schools from the Low group have to travel on average $1.32 \mathrm{~km}$ to find a higher classified school, the distance for parents in the Middle-Low and Middle groups is $0.67 \mathrm{~km}$ and $0.41 \mathrm{~km}$ respectively.

However, the existence of nearby higher quality alternatives does not imply that families can enroll their children in these schools. They may not have the capacity (and willingness) to absorb more students. To estimate the capacity, school infrastructure data, which is not available for Chile, is required. ${ }^{14}$ Thus, to estimate the potential demand for vacancies and the available supply, we calculated the number of students enrolled in "In Recovery" schools, at an aggregate level, and compared this figure to the total enrollment in higher classified schools. At

13 Schools where 20 or less students on average have taken the SIMCE test are not considered higher ranked alternatives, neither are those that have had less than two measurements, since MINEDUC considers that from a statistical point of view, these results are insufficient to make inferences on student performance and, therefore, insufficient to be used for this classification.

14 The Ministry of Education (MINEDUC) has data on school infrastructure; however it is not up-to-date and focuses mainly on the surface area of school buildings rather than on the potential enrollment capacity. 

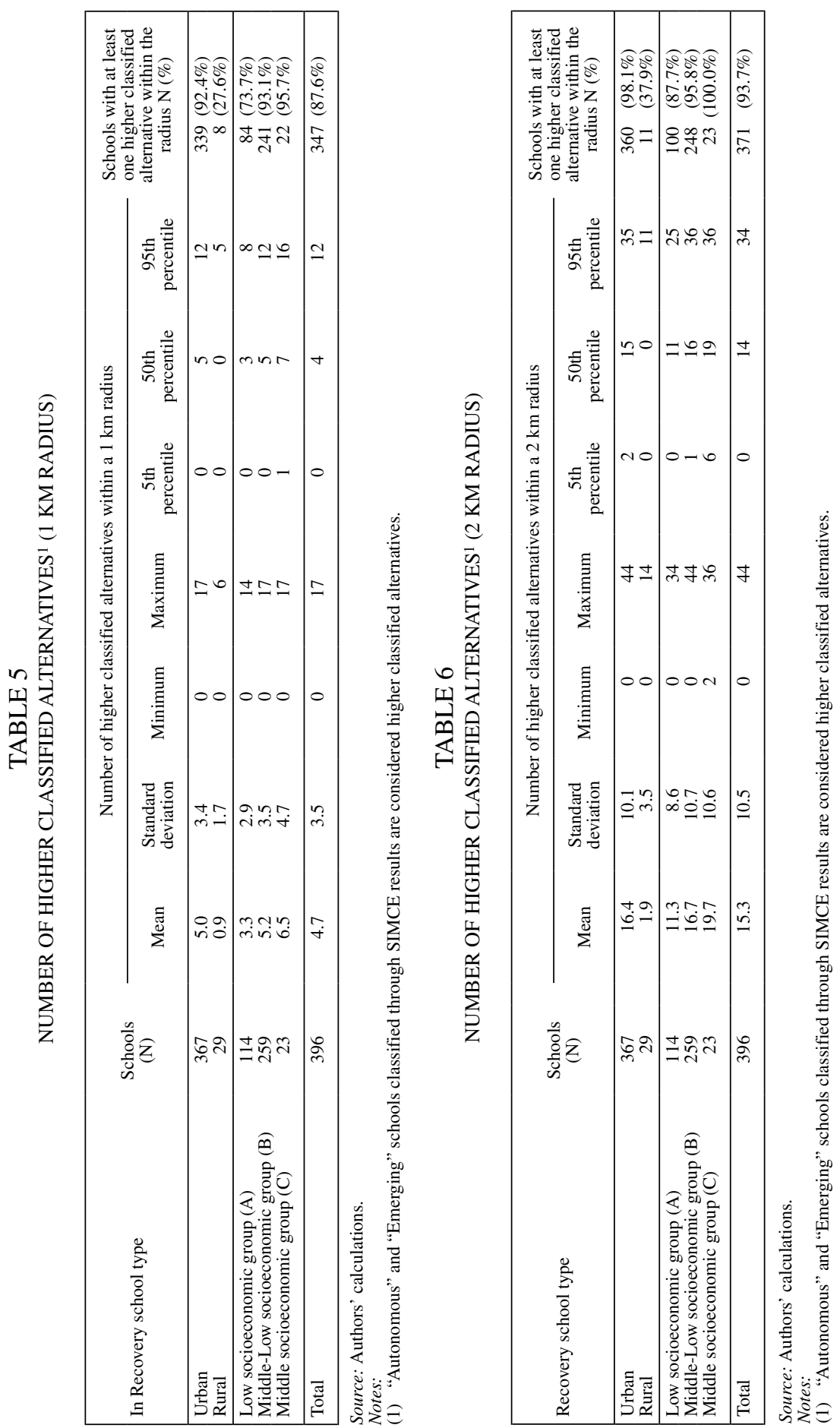


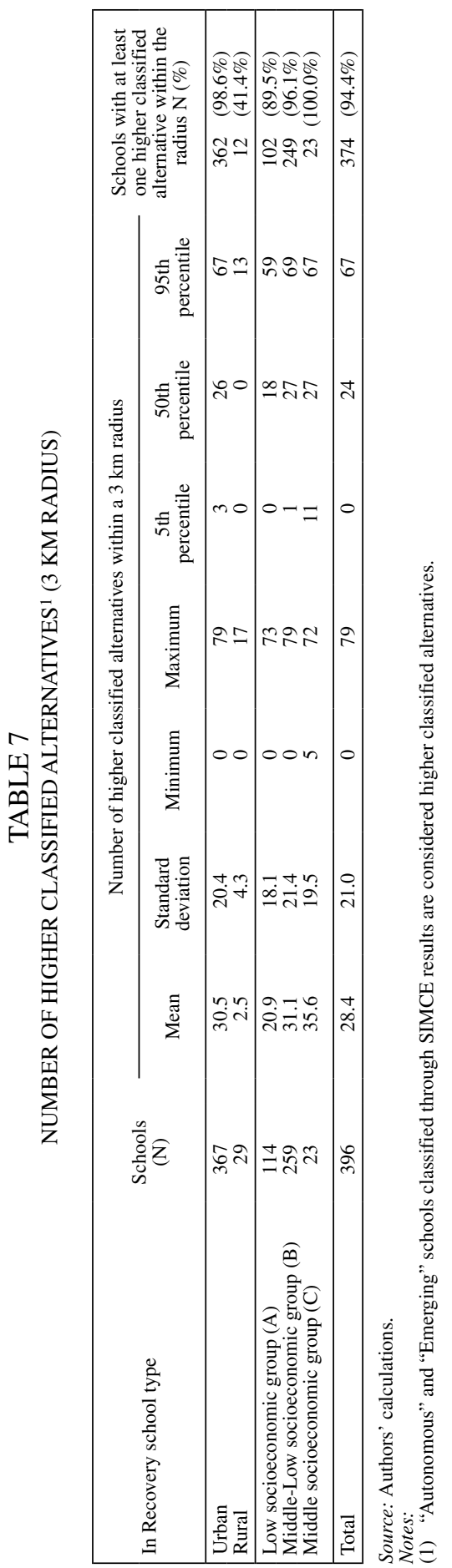

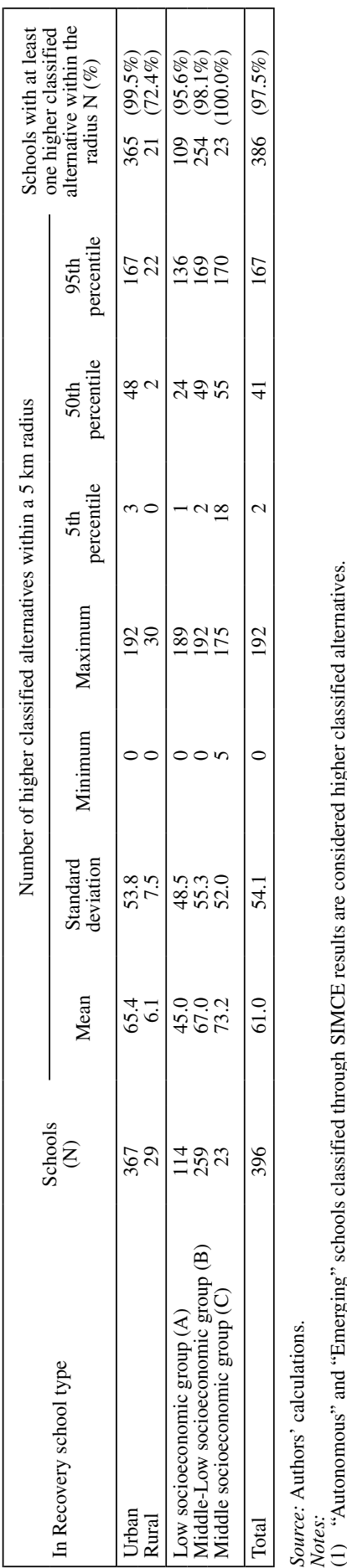




\section{TABLE 9}

\section{DISTANCE TO THE NEAREST HIGHER CLASSIFIED ALTERNATIVE ${ }^{1}$}

\begin{tabular}{|lcccccc|}
\hline & & \multicolumn{5}{c|}{ Distance (km) } \\
\cline { 3 - 7 } In Recovery school type & $\begin{array}{c}\text { Schools } \\
(\mathrm{N})\end{array}$ & Minimum & Mean & $\begin{array}{c}50 \text { th } \\
\text { percentile }\end{array}$ & Maximum & $\begin{array}{c}\text { Standard } \\
\text { deviation }\end{array}$ \\
\hline $\begin{array}{l}\text { Urban } \\
\text { Rural }\end{array}$ & 367 & 0.02 & 0.56 & 0.39 & 25.97 & 1.43 \\
\hline $\begin{array}{l}\text { Low socioeconomic } \\
\text { group (A) }\end{array}$ & 29 & 0.16 & 4.39 & 3.75 & 38.77 & 7.01 \\
$\begin{array}{l}\text { Middle-Low socioeconomic } \\
\text { group (B) }\end{array}$ & 259 & 0.02 & 0.67 & 0.38 & 25.97 & 1.81 \\
$\begin{array}{l}\text { Middle socioeconomic } \\
\text { group (C) }\end{array}$ & 23 & 0.10 & 0.41 & 0.33 & 1.67 & 0.33 \\
\hline Total & 396 & 0.02 & 0.84 & 0.40 & 38.77 & 2.53 \\
\hline
\end{tabular}

Source: Authors' calculations.

Notes:

(1) "Autonomous" and "Emerging" schools classified through SIMCE results are considered higher classified alternatives.

an aggregate level, there are 125,510 students in "In Recovery" schools that have a higher classified school available within a1 km radius $(90 \%$ of students in "In Recovery" schools). Total enrollment in the latter is 578,791 students. Therefore, total enrollment in the higher classified schools needs to increase by $21.7 \%$ to absorb the potential demand of students from "In Recovery" schools. ${ }^{15}$

\subsection{Higher quality alternatives in a school choice system}

Analyzing the alternatives available to families is more complex in a system where parents can choose their children's school and where there are a variety of schooling alternatives available. In this section, to incorporate the specific aspects of the Chilean school choice system, the classification of the nearby alternatives includes, on the one hand, the school entry barriers for families (price and ability selection) and on the other, parental preferences (educational mission and social composition). In each of these dimensions, we established a criterion for defining when the school alternative is accessible. We considered the characteristics of the "In Recovery" schools and the alternative schools, and the findings in the literature on school choice. We used the following definitions:

15 Some calculations were made on the number of slots available per school (based on differences in class size within the same school and on historical enrollment figures). However, when comparing these calculations to the "real" data gathered in a face-to-face survey on a sample (not representative) of 32 principals of alternative schools, we found that in some cases the calculations were underestimating and in others overestimating the number of vacancies available. The results of these exercises are available upon request. 
a) Affordability: A school alternative is considered affordable when the average monthly fees are lower than or equal to those of the "In Recovery" school.16

b) Ability Selection: A school alternative is considered accessible when it does not have admission's exams. ${ }^{17}$

c) Educational mission: A school alternative is considered accessible in educational mission when the religious denomination ${ }^{18}$ of the school is the same as that of the "In Recovery" school. ${ }^{19}$

d) Student Demographics: In this case, parental preference 20 for a given social composition depends on the socioeconomic level of the "In Recovery" school. Families in "In Recovery" schools of group A are assumed to prefer schools from group A or B. Families from group B schools are assumed to prefer schools from groups B, C or D. Finally, families in group C schools prefer schools from group C or D. ${ }^{21}$

Once the accessibility criteria are defined, the alternatives available in the neighborhood of the "In Recovery" schools are classified. In this analysis, we used the radius of $1 \mathrm{~km}$ around the school to define neighborhood. To simplify the analysis, the 2,609 alternatives available for all "In Recovery" schools were grouped into five categories: Type I: Same classification or with insufficient information for classification; Type II: Selective/Preferred/Higher classified; Type III: Selective/Not preferred/Higher classified; Type IV: Not-selective/Preferred/

16 Schools are grouped into five categories: i) Free; ii) Charge less than 9,094 CLP; iii) Charge between 9,095 CLP and 18,190 CLP; iv) Charge between 18,191 CLP and 36,380 CLP and v) Charge between 36,381 CLP and 72,760 CLP.

17 The 2009 fourth grade SIMCE parent questionnaire includes a question on the information requested from parents when enrolling their children at the school. Following Contreras et al. (2010), a school is considered to have ability selection when over $50 \%$ of parents indicate that their children had to take an admission's exam.

18 Depending on religious denomination, schools are classified into Secular, Catholic and Protestant. See footnote 11.

19 Elacqua et al. (2006) shows that nearly $70 \%$ of parents in the Metropolitan Region that consider more than one school option only consider schools with the same religious denomination. Meanwhile, a 2009 Universidad Diego Portales survey of parents in the Metropolitan Region finds that over $60 \%$ considered their second choice a school with the same religious denomination.

20 These decisions reflect both the preferences of parents and their perception of which schools are accessible (i.e. parents limit their choices to feasible alternatives). Thus, more than capturing real parental preferences, the above data corresponds to their preferences subject to their perception of accessible alternatives. Therefore, when referring to school social composition, both elements are considered simultaneously. For example, according to the face-to-face survey data with 216 "In Recovery" school parents in 2011, $42 \%$ of parents would not enroll their children in a higher income school. One of the reasons given for this is affordability, in other words, the assumption of not being able to afford a school with those characteristics, and the impression that their children would suffer discrimination.

21 Using data from the same survey of parents in the Metropolitan Region (see footnote 19), the socioeconomic group of the present school was compared to that of the second choice in order of preference. The results indicate that $94 \%$ of the group A parents considered an A or B school as a second choice, $97.7 \%$ of B group parents considered B, C or D schools, and $96 \%$ of $\mathrm{C}$ group parents considered C or D schools. 
Higher classified and Type $V$ : Not-selective/Not preferred/Higher classified. The "Selective" classification applies to schools whose price is prohibitive for the family (not affordable) or that use ability selection (not accessible due to selection barriers). The "Preferred" classification applies to schools matching parents' preferences in terms of socioeconomic level (socioeconomic level accessibility) and educational mission (educational mission accessibility). Table 10 presents the classification of the alternative schools.

The data indicates that a significant share of the alternatives are not higher quality options, since they are other "In Recovery" schools or are schools with insufficient information to evaluate their quality (28.4\%). Type $I V$ schools represent only $23.2 \%$ of available options. This type of alternative is likely the most desirable for families, since it matches their preferences and offers better educational results. Table 11 presents the number of Type $I V$ schools available in

TABLE 10

CLASSIFICATION OF ALTERNATIVE SCHOOLS ${ }^{1}$ ACCORDING TO ACCESSIBILITY AND QUALITY

\begin{tabular}{|lcr|}
\hline Alternative school type & $(\mathrm{N})$ & $(\%)$ \\
\hline Type I & 741 & $28.4 \%$ \\
Type II & 638 & $24.5 \%$ \\
Type III & 490 & $18.8 \%$ \\
Type IV & 606 & $23.2 \%$ \\
Type V & 134 & $5.1 \%$ \\
\hline Total & 2,609 & $100.0 \%$ \\
\hline
\end{tabular}

Source: Authors' calculations.

Notes:

(1) Since a school can be classified as an alternative in more than one "In Recovery" school, in this table is considered the total number of times it appears as an alternative school.

TABLE 11

TYPE IV ALTERNATIVE SCHOOLS (1 KM RADIUS)

\begin{tabular}{|lrc|}
\hline \multirow{2}{*}{ Type IV schools (N) } & \multicolumn{2}{c|}{ In Recovery schools } \\
\cline { 2 - 3 } & $(\mathrm{N})$ & $(\%)$ \\
\hline 0 & 94 & $23.7 \%$ \\
1 & 95 & $24.0 \%$ \\
2 & 73 & $18.4 \%$ \\
3 & 49 & $12.4 \%$ \\
4 & 32 & $8.1 \%$ \\
5 & 9 & $2.3 \%$ \\
6 & 4 & $1.0 \%$ \\
7 & 3 & $0.8 \%$ \\
Without alternatives (1) & 37 & $9.3 \%$ \\
\hline Total & 396 & $100.0 \%$ \\
\hline
\end{tabular}

Source: Authors' calculations.

Notes:

(1) "In Recovery" schools without alternative schools (of any kind) in a $1 \mathrm{~km}$ radius. 
$1 \mathrm{~km}$ radius around each "In Recovery" school. The data shows that 94 (23.7\%) of the 396 "In Recovery" schools do not have Type $I V$ schools within a $1 \mathrm{~km}$ radius and $265(66.9 \%)$ have at least one school of this type within that radius. Of these, most have only one $(24 \%)$ or two options $(18.4 \%)$.

\subsection{Extensions}

Thus far, we have assumed that schools with a higher SEP classification ("Emerging" and "Autonomous") are higher quality alternatives for parents in "In Recovery" schools. However, the SEP classification methodology is based on a range of arbitrary thresholds of SIMCE results, which suggests that schools near the thresholds do not differ significantly. In fact, Graphs 1, 2 and 3 show that the average SIMCE results of "In Recovery" schools do not differ significantly from those of "Emerging" schools that are located around the cut-off point of the classification (220 points).

This problem is not limited to the SEP classification. In other education accountability systems the evidence also shows that the alternatives available to families are often not significantly higher-performing than the current low-performing school of origin (e.g. Kim and Sunderman, 2004). Moreover, considering the costs associated with changing schools (psychological effects on students and their families, search costs for new schools, etc.; e.g. Ravitch, 2010), it is important to determine if the net gains in academic results actually compensate for the high costs of changing schools.

DISTRIBUTION OF SIMCE TEST SCORES

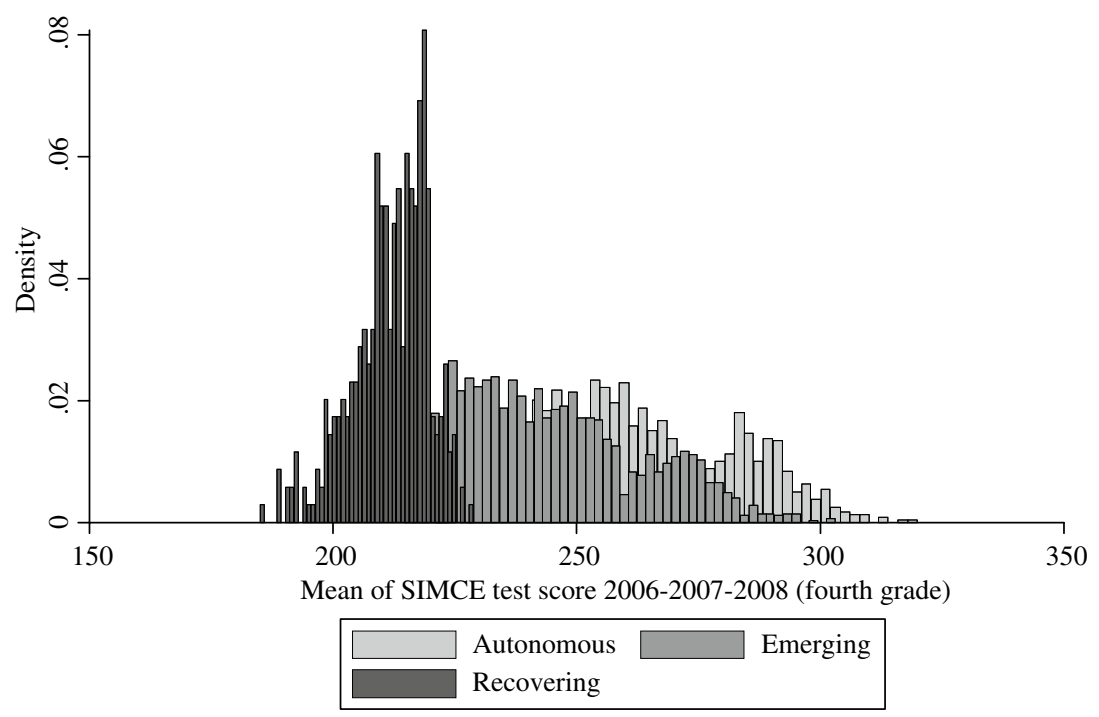

Source: Authors' calculations. 

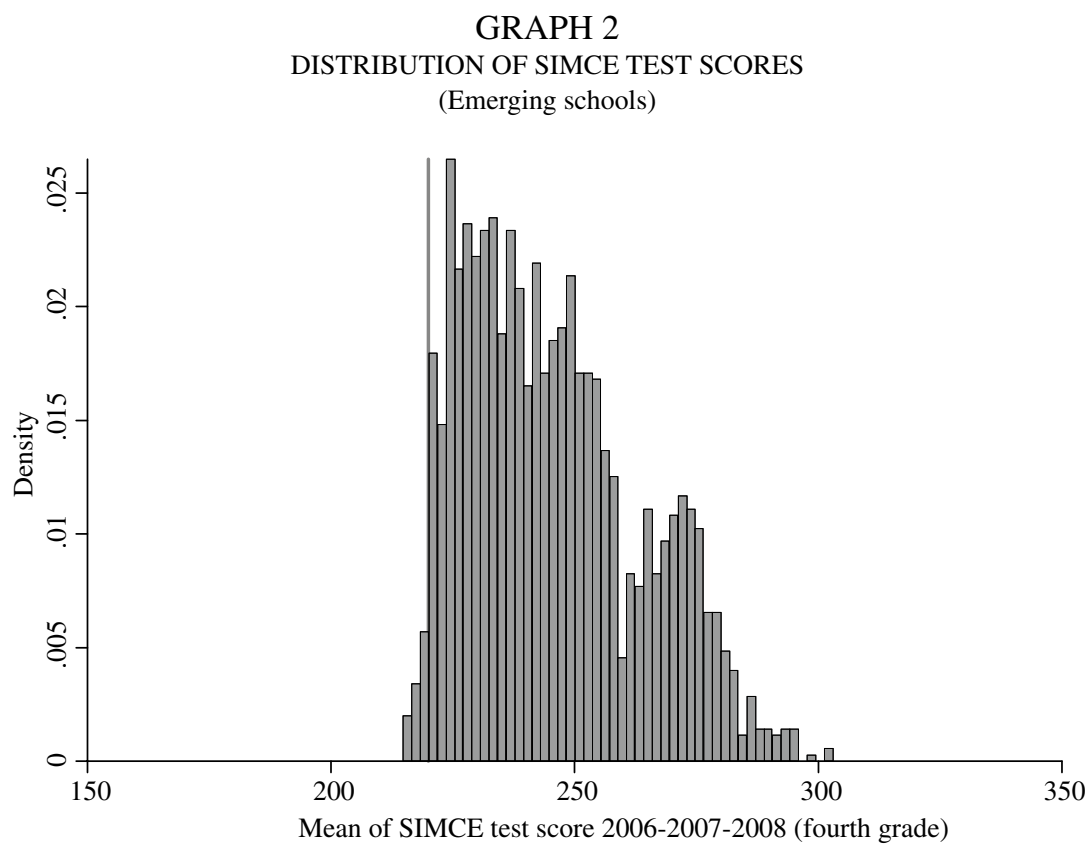

Source: Authors' calculations.
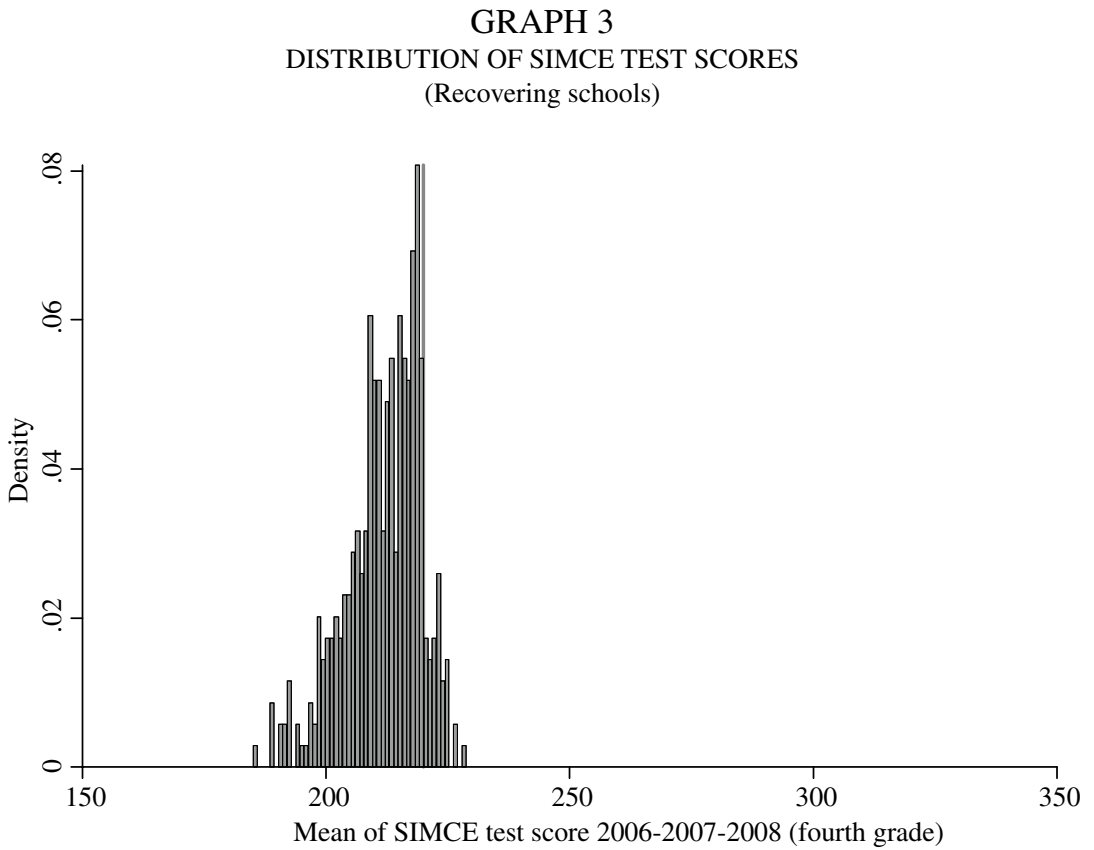

Source: Authors' calculations. 
To incorporate the above in our analysis, in this section, a school is considered higher-performing when, apart from being classified as "Emerging" or "Autonomous", it has a higher Attainment Level than "In Recovery" schools' both on the SIMCE Mathematics and Language exams. ${ }^{22}$

The results of Table 12 show, as expected, that the percentage of Type $I$ alternatives nearly double when the Attainment Level restriction is applied. In this new scenario, less than half of the alternatives would be classified as higher quality schools $(46.3 \%)$. This implies that, in practice, many of the schools available to families with children enrolled in "In Recovery" schools do not offer significant improvements in SIMCE results, despite having a higher SEP classification.

Another relevant extension is to consider the ownership status of the alternative schools. This is important because there are major differences in the autonomy of decision-making between private and public schools. For example, many private voucher schools offer more personalized classes as part of their educational mission. In this case, even though the school may have the physical space to accept more students, it would likely choose not to do so because that would go against the school's educational mission. While it is true that the Ministry

TABLE 12

CLASSIFICATION OF ALTERNATIVE SCHOOLS ${ }^{1}$ ACCORDING TO ACCESSIBILITY AND QUALITY

\begin{tabular}{|c|c|c|c|c|}
\hline \multirow{3}{*}{ Alternative school type } & \multicolumn{4}{|c|}{ Higher quality school definition } \\
\hline & \multicolumn{2}{|c|}{ SEP Law Classification } & \multicolumn{2}{|c|}{$\begin{array}{c}\text { SEP Law } \\
\text { Classification+Attainment } \\
\text { Level }\end{array}$} \\
\hline & $(\mathrm{N})$ & $(\%)$ & $(\mathrm{N})$ & $(\%)$ \\
\hline Type I & 741 & $28.4 \%$ & 1,428 & $54.7 \%$ \\
\hline Type II & 638 & $24.5 \%$ & 508 & $19.5 \%$ \\
\hline Type III & 490 & $18.8 \%$ & 424 & $16.3 \%$ \\
\hline Type IV & 606 & $23.2 \%$ & 180 & $6.9 \%$ \\
\hline Type V & 134 & $5.1 \%$ & 69 & $2.6 \%$ \\
\hline Total & 2,609 & $100.0 \%$ & 2,609 & $100.0 \%$ \\
\hline
\end{tabular}

Source: Authors' calculations.

Notes:

(1) Since a school can be classified as an alternative in more than one "In Recovery" school, in this table is considered the total number of times it appears as an alternative school.

22 Student attainment levels are classified into three categories based on their performance on the SIMCE test: Initial, Intermediate, and Advanced. They are used to indicate if students have attained the skills and knowledge required for their grade level. For example, a student who has attained the Advanced Level has achieved the expected outcomes for his/her grade level. The SIMCE point thresholds are: Language (Initial: $<241.5$; Intermediate: $\geq 241.5$ and $<281.5$; Advanced: $\geq 281.5$ ). Mathematics (Initial: $\leq 233.5$; Intermediate: $\geq 233.5$ and $\leq 286.5$; Advanced: $\geq 286.5$ ). 
TABLE 13

CLASSIFICATION OF ALTERNATIVE SCHOOLS ${ }^{1}$ ACCORDING TO ACCESIBILITY, QUALITY AND SCHOOL OWNER TYPE

\begin{tabular}{|lrr|}
\hline & \multicolumn{2}{c|}{ SEP Law Classification+Attainment Levels } \\
\cline { 2 - 3 } Alternative school type & $(\mathrm{N})$ & $(\%)$ \\
\hline Municipal & & \\
Type I & 761 & $29.2 \%$ \\
Type II & 27 & $1.0 \%$ \\
Type III & 1 & $0.0 \%$ \\
Type IV & 131 & $5.0 \%$ \\
Type V & 32 & $1.2 \%$ \\
\hline Private voucher & & \\
Type I & 667 & $25.6 \%$ \\
Type II & 481 & $18.4 \%$ \\
Type III & 423 & $16.2 \%$ \\
Type IV & 49 & $1.9 \%$ \\
Type V & 37 & $1.4 \%$ \\
\hline Total & 2,609 & $100.0 \%$ \\
\hline
\end{tabular}

Source: Authors' calculations.

Notes:

(1) Since a school can be classified as an alternative in more than one "In Recovery" school, in this table is considered the total number of times it appears as an alternative school.

of Education has the authority to regulate school selection processes ${ }^{23}$ it does not set minimum class size and the number of slots private schools can offer. ${ }^{24}$

Table 13 presents the distribution of the alternatives based on accessibility, quality and ownership status. The results indicate that of the 1,401 Type $I$ schools, 761 are municipal, and the rest are private voucher (667). As expected, most higher-quality private voucher alternatives are selective, either through price or selection. These results suggest that the use of selection mechanisms is still a common practice in private voucher schools, despite being prohibited by law. In contrast to the above, most alternatives that are not selective and preferred by parents (Type $I V$ ) are municipal schools. ${ }^{25}$

23 Private voucher schools cannot administer tests or interviews to students from pre-kinder to $6^{\text {th }}$ grade. From $7^{\text {th }}$ grade through high school, schools can use cognitive admissions tests to select students. See General Education Law (LGE).

24 A significant part of the facilities of private voucher schools has been funded by the State through the Supplementary Contribution for Additional Capital Cost program (Programa de Aporte de Capital), which offers some scope for control of the use of the buildings. Throughout 2002-2011 this program provided over 1,700 million dollars to subsidized schools (public and private). The specific objective of this program is to support schools whose infrastructure is insufficient to join the full school day (Jornada Escolar Completa or JEC).

25 School selection likely persists in Chile due to the lack of supervision of school admission processes. For example, there is no public information on the fines or sanctions applied to schools that have violated the law. 


\section{Conclusions and Public Policy Discussion}

In Chile, the Adjusted Voucher Law (Ley SEP), enacted in 2008, was the first to establish a school accountability system that introduced performance goals and sanctions to schools with low educational outcomes. If schools do not meet the objectives set out in the SEP Law, they can be closed and their students will be required to find other schooling options. To analyze the scenarios facing these families, this study identifies, characterizes, and geographically locates the low-performing schools and their nearby alternatives, evaluating their availability, accessibility, and quality.

An initial result is that many families in low-performing schools would not have nearby higher quality schooling options if their school was closed. In effect, $28.4 \%$ of available alternatives are other "In Recovery" schools or are schools for which there is insufficient information to evaluate their quality. This limitation mainly affects rural and low-SES schools, which implies that, in these schools, the possibility of closure could lead to high costs for families. While a transport subsidy could be a viable policy option in urban areas, the results suggest that for many rural schools there are no quality options available even within a considerable distance $(5 \mathrm{~km})$. In this case, targeted interventions may be the only way to ensure access to a quality education. Researchers have asserted that it is important to complement the local background analysis of schools and their local markets with a diagnostic of their internal capacities, to determine if the schools have the potential to improve their results (e.g. Elmore, 2010).This analysis is essential to determine if a technical intervention is the best option to improve failing schools in isolated areas or if it is better to explore other alternatives including the entry of new schools.

After incorporating aspects of Chile's system of school choice in the analysis (accessibility and parental preferences), the results suggest that parents have even fewer feasible alternatives available in their neighborhoods. In practice, many of the quality alternatives close to the low-performing schools are not accessible for all families, since schools select students through ability tests and parental interviews and/or charge monthly fees. Also, in a school choice system, families aspire to choose a school that most closely matches their preferences, and so being forced to choose a school with a different educational mission would likely decrease their satisfaction. When these issues are taken into account, there is a significant percentage of low-performing schools that do not have nearby school options that are higher quality, accessible, and preferred by parents. Specifically, only $23.2 \%$ of the available alternatives are consistent with parental preferences and do not have entry barriers. This suggests that the way to improve the options available to families must include additional considerations other than those based strictly on nearby higher quality alternatives. While the General Law of Education forbids student selection until sixth grade and the SEP Law exempts disadvantaged students from paying school fees, many families still do not have access to quality schools in their neighborhoods since selection practices persist in many schools. This poses challenges for the enforcement of this law, which is one of the functions of the Superintendency of Education (Superintendencia de Educación). Additionally, the option of transferring students to higher quality schools that are further away should be explored, as well as analyzing the 
implementation of interventions to turn around low performance schools, when none of the above options are feasible.

Finally, if more stringent criteria are applied to define quality schools, the alternatives available to families decline. Specifically, over half of the alternatives would be classified as being of a similar quality as the "In Recovery" schools or with insufficient information to classify (54\%). This indicates that, in practice, many of the schools available to families do not offer significant improvements in terms of SIMCE results, despite having a higher SEP classification. Therefore, the SEP classification -or future accountability rankings- should include tighter quality definition to ensure that students in low-performing school are moving to a higher quality school. This is a challenge for the Education Quality Agency, which will begin to classify all schools nationwide. Although the classification will largely depend on the SIMCE scores, the cut-off points need to be discussed in terms of student learning levels, in order to ensure that the alternatives provided to families offer a significant improvement.

Regarding the practical implementation of the SEP Law, there are two additional challenges to keep in mind. The first is the lack of reliable information on potential enrollment in schools. Since students will be moved from lowperforming schools to higher quality ones, reliable information is needed on the maximum capacity available per school. This information can be gathered through a school infrastructure survey or census to determine the effective physical capacity of schools. This data is crucial for determining the feasibility of transferring students from "In Recovery" schools to nearby higher quality alternatives. Second, according to our simulation, $75 \%$ of schools classified as "In Recovery" are municipal schools. This data suggests an implementation challenge for the Ministry of Education, which would probably face a difficult political scenario when applying this measure in public schools.

Finally, it should be pointed out that due to the short time elapsed since the application of the "In Recovery" category, the results of this study are based on a static scenario in which low-performing schools do not manage to improve their educational results, alternative schools do not react in the short term changing their admission policies or installed capacity, and new schools that could offer more efficient services do not enter the market.

In summary, this study provides valuable information for the practical application of the sanctions established in the SEP Law. Nevertheless, there are some questions arising from the findings contained here that are beyond the scope of this work and could be addressed in future research. For example, will higher-performing schools be willing to enroll students (most lagging behind their grade level) from failing schools? Do some low-performing schools have better internal capacities to improve their performance than others? What are the consequences of school closure for the community where the failing school is located? What are some of the determinants that could help explain the scarcity of quality alternatives in certain neighborhoods? These questions and others are key to understanding the costs and benefits of incorporating the measure of school closure in school accountability programs. 


\section{REFERENCES}

Allen, R., and S. Burgess (2012). How should we treat under-performing schools? A regression discontinuity analysis of school inspections in England. The Centre for Market and Public Organisation, Working Paper 12/287. Accessed from: http://www.bristol.ac.uk/cmpo/publications/ papers/2012/wp287.pdf

Alves, F., M. Koslinski, G. Elacqua and H. Santos (August, 2012). The Effects of School Choice on Equity: Evidence from Rio de Janeiro, Brazil and Santiago, Chile. Paper presented at the Conference "Labor Market and Education Transitions in Uncertain Times". Charlottesville, VA, USA.

Brady, R. (2003). "Can Failing Schools be fixed?", Thomas B. Fordham Foundation. Accessed from: http://www.edexcellence.net/publications/ canfailingschools.html

Chubb, J. and Moe, T. (1990). Politics, markets, and America's schools. Washington, D.C.: Brookings Institution Press.

Chumacero, R. A., D. Gómez and R. Paredes (2011). "I would walk 500 miles (if it paid): Vouchers and school choice in Chile". Economics of Education Review, Vol. 30, 1103-1114.

Contreras, D., P. Sepúlveda and B. Bustos (2010). "When schools are the ones that choose: The effects of screening in Chile", Social Science Quarterly, Vol. 91; 1349-1368.

Dillon, E. (2008). "Plotting School Choice: The challenges of crossing district lines". Washington D.C.: Education Sector Reports.

Elacqua, G. and Santos, H. (in press). "Preferencias reveladas de los proveedores de educación en Chile: El caso de la Ley SEP”, Gestión y Política Pública.

Elacqua, G., M. Schneider and J. Buckley (2006). "School Choice in Chile: Is it Class or Classroom", Journal of Policy Analysis and Managment, Vol. 25; 577-601.

Elmore, R. (2010). Mejorando la Escuela desde la Sala de Clases. Santiago: Área de Educación Fundación Chile.

Figlio, D. and L. Getzler (2002). "Accountability, Ability and Disability: Gaming the System?”. En T. Gronberg y D. Jansen. Improving School Accountability: Check-Ups or Choice, Advances in Applied Microeconomics. Amsterdam: Elsevier Science.

Fiske, E. and H. Ladd (2000). When schools compete: A cautionary tale. Washington, D.C.: The Brookings Institution Press.

Friedman, M. (1962). Capitalism and freedom. Chicago, IL: The University of Chicago Press.

Gallego, F. and A. Hernando (2008). "School choice in Chile: Looking at the demand side". Documento de Trabajo N ${ }^{\circ}$ 356, Instituto de Economía, Pontificia Universidad Católica de Chile. Accessed from: http://www. economia.puc.cl/DT?docid $=3343$

Hanushek, E. and L. Woessmann (2012). "Schooling, educational achievement, and the Latin American growth puzzle". Journal of Development Economics 99 (2), November 2012, pp. 497-512.

Hanushek, E., J. Kain and S. Rivkin (2004). "Disruption versus Tiebout Improvement: The Costs and Benefits of Switching Schools". Journal of Public Economics 88 (9), August 2004, pp. 1722-1746. 
Kim, J. and G. Sunderman (2004). "Does NCLB provide good choices for students in low performing schools?" Cambridge, MA: The Civil Rights Project at Harvard University.

Lacireno-Paquet, N., T. Holyoke, M. Moser and J. Henig (2002). "Creaming versus cropping: Charter school enrollment practices in response to market incentives", Educational Evaluation and Policy Analysis, Vol. 24; 145-158.

Lubienski, C., C. Gulosino and P. Weitzel. (2009). "School Choice and Competitive Incentives: Mapping the distribution of educational opportunities across local education markets", American Journal of Education, Vol. 115; 601-647.

Mathis, W. (2009). "NCLB's Ultimate Restructuring Alternatives: Do they improve the quality of education?" The Great Lakes Center for Education Research and Practice.

Murphy, J. and C. Meyers (2007). “Turning around Failing Schools: Leadership lessons from the organizational sciences". Thousand Oaks, CA: Corwin Press.

Ravitch, D. (2010). "The Death and Life of the Great American School System". New York: Basic Books.

Rouse, C. E., J. Hannaway, D. Goldhaber and D. Figlio (2007). "Feeling the Florida Heat? How Low Performing Schools Respond to Voucher and Accountability Pressure". NBER Working Paper $\mathrm{N}^{\circ} 13681$.

Schneider, M., P. Teske and M. Marschall (2000). "Choosing schools: Consumer Choice and the Quality of American Schools". New Jersey: Princeton University Press.

Smarick, A. (2010). "The turnaround fallacy", Education Next, Vol. 10; 20-26.

Spreng, C. (2005). "Policy Options for Interventions in Failing Schools", RAND Corporation.

The Center for Comprehensive School Reform and Improvement (2010). "School restructuring options under NCLB: What works when? A guide for education leaders". Accessed from: http://www.centerforcsri.org/

The Education Commission of the States (2002). State takeovers and Reconstitutions. Denver: The Education Commission of the States. 